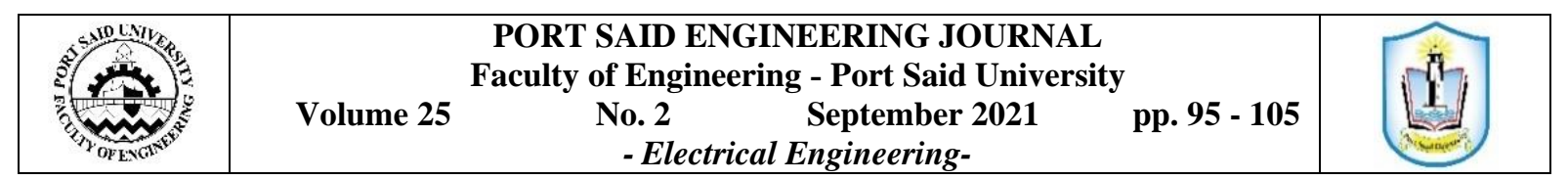

\title{
Sizing of Battery Energy Storage System for Electrical Power Grid with High Penetration Level of Renewable Energy
}

\author{
Mahmoud M. Mashaal ${ }^{l}$, Azza A. ElDesouky², Abdelhay A. Sallam, (LSM, IEEE)
}

\begin{abstract}
Renewable energy resources (RERs), mainly wind and photovoltaic (PV), can be integrated into the power system to reap the gains of clean energy. However, the stochastic output of large-scale RERs introduces many integration challenges on the power system, especially when replacing the conventional generation by RERs. To avoid the power-gap between the generation and demand because of variable sources existence, the energy storage devices (ESDs) are introduced. Batteries that have high energy density and reasonable time response are the appropriate technology for steady state operation. Their sizing is essential for assuring the intact operation of the power system. In this work, the load flow algorithm that emulates a proper battery power profile is used. Then, a developed algorithm to adjust the battery size and its initial value is proposed. Different case studies are presented to comprehensively analyze the impact of RERs integration with the ESDs on the power system operation. The proposed algorithm with the aid of power system analysis toolbox (PSAT) is applied to the medium voltage (MV), IEEE-14 bus test system to validate and emphasize its applicability.
\end{abstract}

Keywords: Renewable energy resources, Energy storage devices, Load flow calculations, Battery sizing, power system analysis toolbox.

\section{INTRODUCTION}

Renewable energy resources (RERs) have become an important source of electrical generation and their importance is continuing to increase. Exhaustion of fossil fuel, expand over oil costs and growth in energy demand are the great motivation to focus on use of renewable energy rather than traditional energy [1]. Hence, high level of renewable energies penetration may be needed to function as conventional thermal power plants with synchronous generators [2].

However, incorporating such RERs in electrical power systems causes some problems because of the fluctuations of their generated power. The real issues of high stochastic renewable generation penetration are their uncertainty and variability[3]-[4]. Meanwhile, replacing fossil fuel-based resources by RERs are becoming a mandate in many countries. An optimal investment plans in new renewable and fossil generation capacity were identified with the goal of achieving significant $\mathrm{CO} 2$ emissions reduction [5].

An important role in managing the variability of renewable output to enable a large scale integration of wind power with the current electricity system was presented in [6].

\footnotetext{
${ }^{I}$ Demonstrator, Electrical power Department, Faculty of Engineering,

Portsaid University, Egypt, Corresponding author, email: mahmoud_meshal@eng.psu.edu.eg

${ }^{2}$ Professor, Electrical power Department, Faculty of Engineering, Portsaid University, Egypt, email: azzaeldesouky@yahoo.com

${ }^{3}$ Professor, Electrical power Department, Faculty of Engineering,

Portsaid University, Egypt, email: abdelhay.sallam@gmail.com
}

Received: 25-03-2021, Accepted: 25-07-2021

DOI: 10.21608/PSERJ.2021.185286
Toward the same time, the wind turbine producers have created another generation of wind turbines, which have the ability to go along with such stringent technical necessities $[7,8]$. Mainly, to mitigate some of the negative impacts of the energy variability supplied by RERs when integrating such resources on large scale, new methods have been proposed in [9]. The effect of large-scale RERs on the power system including thermal generators was quantified in [10-11].

Energy storage devices (ESDs) are commonly integrated with RERs owing to their fast response to reduce the impact of power fluctuation produced by RERs. They have many advantages that can help balancing generation and demand, improving power quality, smoothing the renewable resource's intermittency, and enabling ancillary services in grid operation [12-15]. Battery energy storage system (BESS) is referred to as one of the most important and efficient way of stabilizing electricity network and satisfying the long- term energy request [16-17]. It plays an essential role as it receives the surplus energy to be charged as long as the energy carries are available and discharges the energy into the load whenever it is required [18]. Due to the vital role played by the storage system, its size is an eminent factor for guaranteeing the right operation of the system. Different case studies are considered in this work where wind farms and solar plants replace the conventional power units under different operating conditions.

The main contribution of this paper includes the following:

1- Different case studies to analyze the impact of replacing the conventional sources by RERs on power system steady state operation are 
investigated through use of MV, IEEE-14 bus test system.

2- Determination of battery size using load flow calculations at different power system operating conditions.

3- Proposing a developed algorithm to adjust the battery size and its initial value.

Accordingly, this paper is organized as follows: Section \#2 presents the load flow calculations. Section \#3 describes the structure of the proposed algorithm, whereas the test system and modeling of renewable sources are introduced in Section \#4. The simulation of case studies and results are presented in Section \#5. Finally, the conclusion is presented in Section \#6.

\section{LOAD FLOW CALCULATIONS}

Replacement the conventional sources by RERs has many benefits such as diversifying energy resources and decreasing gas emissions. However, incorporating such sources (e.g., wind farms and PV plants) in electrical power system causes some problems because of the fluctuation of their generated power. This fluctuation adversely affects the power system operation. To beat the stochastic nature of RERs an ESS is used with a size that should be calculated carefully. Therefore, load flow analysis for power system operating at normal conditions incorporating RERs and ESS is developed to get the outputs; line flows, bus voltages, power delivered by each source, system losses and ESS role. Some considerations are taken into account. These are:

- The available capacity of RERs, $P_{\text {ren }}(t)$, is climatictime dependent. Then the powers injected by the RERs into the transmission network are restricted by the available capacity in due time.

- The conventional generating units have a constant power rating. The power received by the system from each unit depends on the system topology, system losses, and load demand.

- The energy storage system (ESS) can inject power into the transmission system during its discharging state and receives power from the system during its charge state, $\operatorname{PESS}(t)$.

- The total load is time variant and its profile is given, $P_{L}(t)$. Fig. 1 depicts the load profile used in this study through 24 hours.

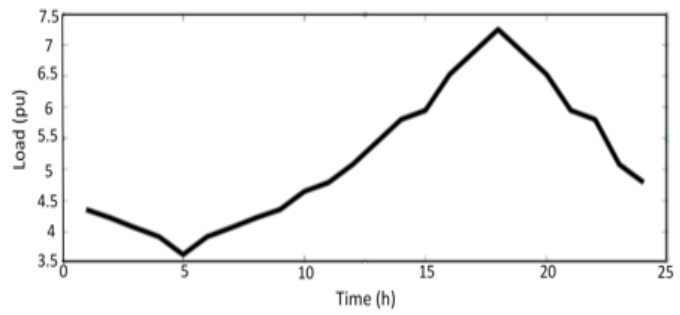

Figure 1: Load profile through 24 hours.
A schematic diagram of the power system configuration as well as the direction of power flow regarding the generating units (conventional and renewable), ESS and loads are illustrated in Fig. 2.

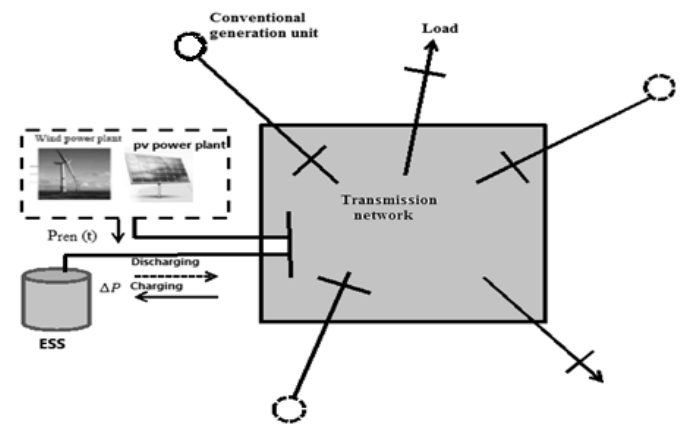

Figure 2: A schematic diagram of a power system with RERs and ESS [19]

The charging/discharging power of the ESS can be denoted as $\Delta P$, which is the difference between the total power generation (conventional and renewable), $P_{G e n}$ and the load, $P_{L}$, including the system losses, $P_{\text {losses }}$. Thus,

$\Delta P(t)=P_{\text {Gen }}(t)-\left[P_{L}(t)+P_{\text {losses }}(t)\right]$

$P_{G e n}(t)=\sum_{g=1}^{N} P_{g}(t)+\sum_{i=1}^{M} P_{r e n, i}(t)$

where $N$ an $M$ are the number of conventional generating units and RERs, respectively. Thus,

$$
\begin{aligned}
P_{E S S}(t) & =\Delta P(t) \text { for } \Delta P(t)>0(\text { ESS as a load }) \\
& =|\Delta P(t)| \text { for } \Delta P(t)<0(\text { ESS as a source })(3) \\
& =0 \text { for } \Delta P(t)=0 \text { (balance state })
\end{aligned}
$$

The power balance condition in (2), can be expressed as:

$$
\begin{aligned}
& P_{\text {Gen }}(t)=\left[P_{L}(t)+P_{\text {losses }}(t)\right] \\
& \left.+P_{E S S}(t)\right]\{\text { charging }\} \\
& P_{G e n}(t)+P_{E S S}(t)=\left[P_{L}(t)+\right. \\
& \left.P_{\text {losses }}(t)\right]\{\text { discharging }\}
\end{aligned}
$$

The calculations of load flow are implemented over 24 hours to obtain the power profile (PESS) of the ESS. Fig. 3 represents the flow chart of the load flow calculations.

\section{THE PROPOSED ALGORITHM FOR BATTERY SIZING}

Based on running the load flow program as described in Section \#2 to calculate $P_{E S S}$, the battery state of charge (SoC) can be calculated as follows:

$$
\operatorname{SoC}(T)=\sum_{t=1}^{T} \operatorname{SoC}_{\text {int }}(t)+\sum_{\mathrm{t}=1}^{\mathrm{T}} \Delta \mathrm{t}\left[P_{c h}(t)-P_{\text {dis }}(t)\right]
$$


$P_{c h, d i s}(t)= \begin{cases}\dot{\eta}_{c h} . P_{E S S}(t) & ; P_{E S S}>0 \\ \frac{P_{E S S}(t)}{\dot{\eta}_{\text {dis }}} & ; P_{E S S}<0\end{cases}$

where $S o C_{\text {int }}$ is the initial state of charge of the EES. This parameter must be arbitrarily computed. In this study, the batteries as they have high energy density are used as ESS. Thus,

$$
P_{E S S}(t)=P_{\text {batt }}(t)
$$

In general, to prolong the life of the battery [20], minimum and maximum SoCs are used. The stored energy is bounded as follows:

$$
\operatorname{SoC}(t)=\operatorname{SoC}(t-1)+P_{E S S}(t) \cdot \Delta T \cdot \dot{\eta}_{d} \text { charging mode }
$$

$\operatorname{SoC}(t)=\operatorname{SoC}(t-1)-P_{E S S}(t) \cdot \Delta T / \dot{\eta}_{d}$ discharging mode

where,

$P_{E S S}(t)$ : ESS power output at the $t$-th commitment interval

SoC $(t)$ : State of charge at the end of the $t$-th commitment interval

$\Delta T$ :Duration of the interval, in hours ( $1 \mathrm{~h}$ in this study)

$t=1,2,3, \ldots . \mathrm{T} ; \mathrm{T}=24$ hours

$\dot{\eta}_{d}$ : Discharging efficiency.

$\dot{\eta}_{c}$ : Charging efficiency.

An algorithm is implemented to effectively find the acceptable size of the battery satisfying high efficiency.

The proposed algorithm of battery size computation for a time span of $T$ and starting at time $t$ constitutes the following steps:

1- Define the time span (from $t$ to $T$ ) and time increment $\Delta t$. For instance, $t=1$ to $T=24 \mathrm{~h}$ and $\Delta t$ $=1 \mathrm{~h}$.

2- Run load flow algorithm and find the battery power $\left(P_{E S S}(t)\right)$ as expressed in (3).

3- Initialize both the initial and battery state of charge $S o C_{\text {int }}(t)$ and $S o C(t)$ to equal zero.

4- If $t \leq T$, calculate the battery $\operatorname{SoC}(\mathrm{t})$ according to (6), else go to step \#10.

5- If $S o C(t)<0$, then $S o C_{\text {int }}(t)=|S o C(t)|+$ $S o C_{\text {int }}(t), \operatorname{SoC}(t)=S o C_{\text {int }}(t)$, go to step \#4.

6- If $\operatorname{SoC}(t)<\operatorname{Soc}(t-1)$,

$\operatorname{SoC}(t)=\operatorname{SoC}(t-1)-P_{E S S}(t) . \Delta T / \dot{\eta}_{d}$, go to step \#9.

7- If $\operatorname{SoC}(t)>\operatorname{Soc}(t-1), \operatorname{SoC}(t)=\operatorname{SoC}(t-1)+$ $P_{E S S}(t) \cdot \Delta T \cdot \eta_{d}$, go to step \#9.

8- If $\operatorname{SoC}(t)=\operatorname{SoC}(t-1)$, go to step \#9.

9- Advance $t \rightarrow t+\Delta t$, go to step \#4

10- Stop

Fig. 4 shows the flowchart of the proposed algorithm.

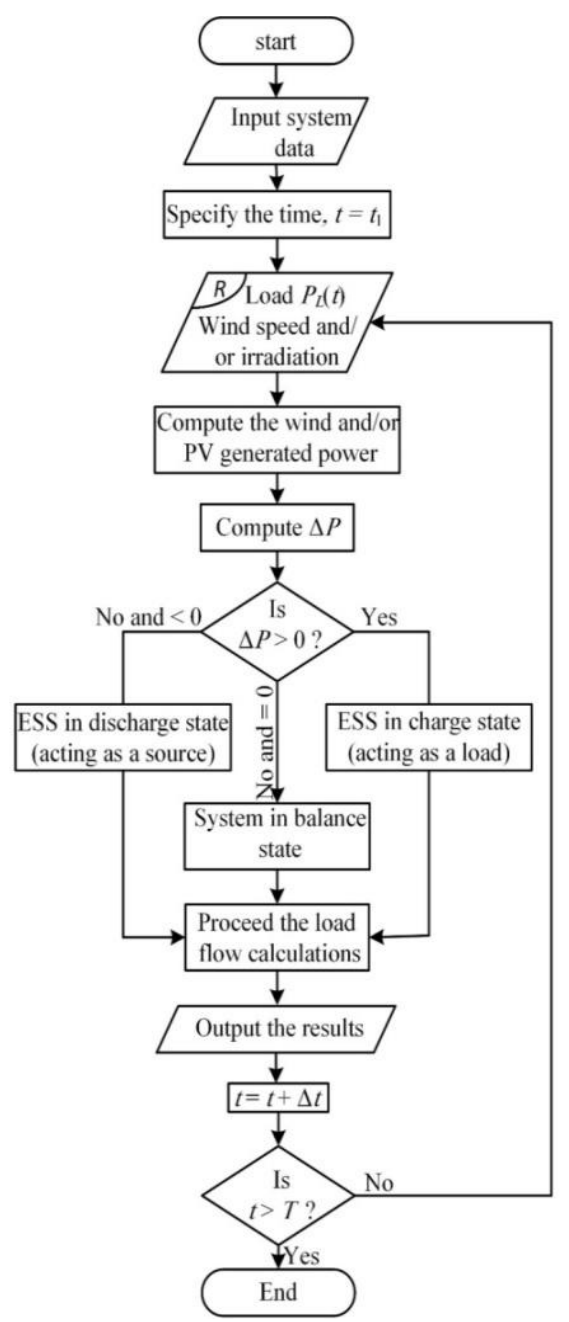

Figure 3: Load flow calculations

\section{TEST SYSTEM}

The IEEE 14-bus is used as a test system to investigate the impact of replacement of conventional sources by RERs on power system steady state operation as shown in Fig.5. It comprises five generators: two generators at buses \#1and $\# 2$, which are responsible for generating active power. The other generators at buses \#3, \#6 and \#8 are synchronous compensators. The system is divided into two regions; the first region (area \#1) operates at a voltage of $69 \mathrm{kV}$ and the second (area \#2) at $38 \mathrm{kV}$.

Three case studies are proposed depending on the way of replacement of conventional generators of the test system by wind farm and solar photovoltaic (PV) plant as in the following:

- Case \#1: the conventional generator at bus \#1 is replaced by a wind farm with the same rated power.

- Case \#2: the conventional generator at bus \#2 is replaced by a PV plant with the same rated power.

- Case \#3: the generators at both bus \#1 and bus \#2 are replaced by wind farm and PV plant, respectively. 
To investigate the case studies, the mathematical modeling of both wind farm and PV plant are required. However, these models are briefly described as below. It is assumed that the RERs are equipped with a compensator to provide the reactive power when needed.

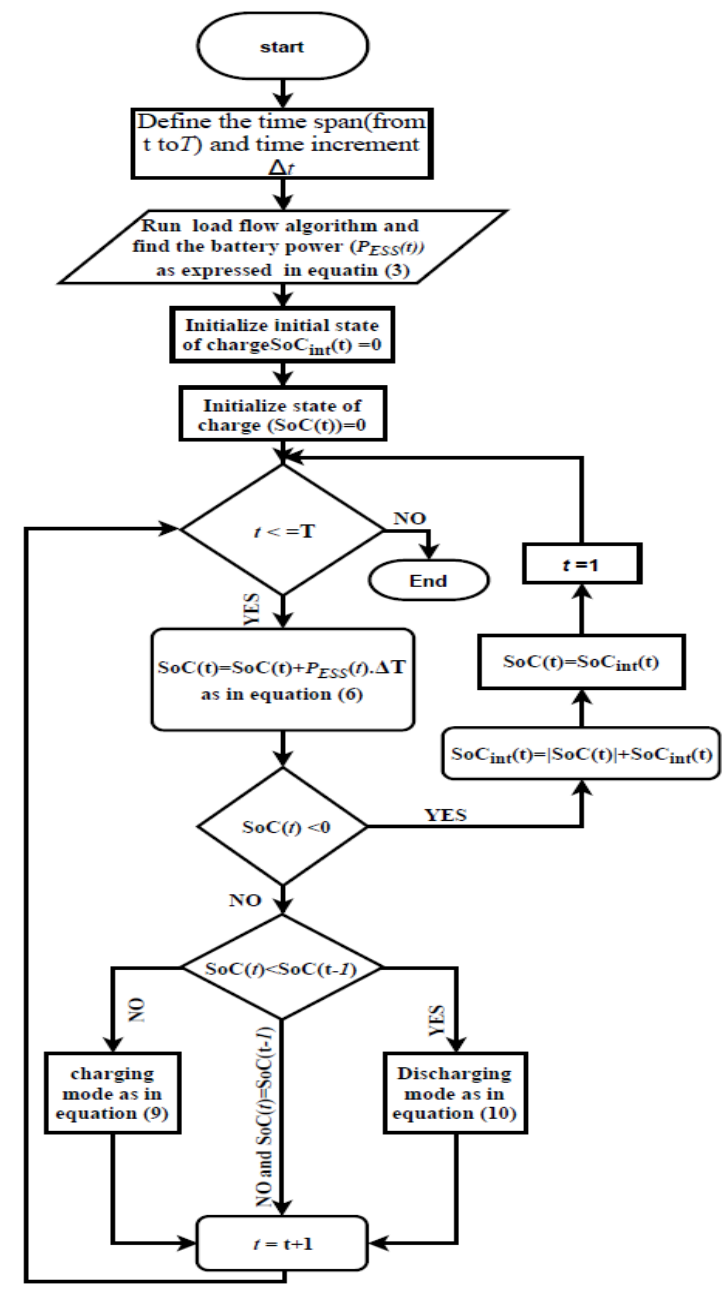

\section{Figure 4: The proposed algorithm for calculating battery size and its initial value}

\subsection{Wind Farm Model}

This model is structured by the mathematical equations that represent the Doubly Fed Induction Generator (DFIG) and the power extracted from the wind farm. The DFIG with variable speed wind turbine is used in this study as shown in Fig. 6. The steady-state electrical equations are as in the following:

$$
\begin{aligned}
& v_{d s}=-r_{s} i_{d s}+\left(\left(x_{s}+x_{m}\right) i_{q s}+x_{m} i_{q r}\right) \\
& v_{q s}=-r_{s} i_{q s}-\left(\left(x_{s}+x_{m}\right) i_{d s}+x_{m} i_{d r}\right. \\
& v_{d r}=-r_{r} i_{d r}+\left(1-w_{m}\right)\left(\left(x_{s}+x_{m}\right) i_{q r}+x_{m} i_{q s}\right. \\
& v_{q r}=-r_{r} i_{q r}-\left(1-w_{m}\right)\left(x_{s}+x_{m}\right) i_{d r}+x_{m} i_{d s}
\end{aligned}
$$

where $v_{d s}, v_{q s}$, and $v_{d r}, v_{q r}$ are $d$ and $q$ components of stator and rotor voltage, respectively.

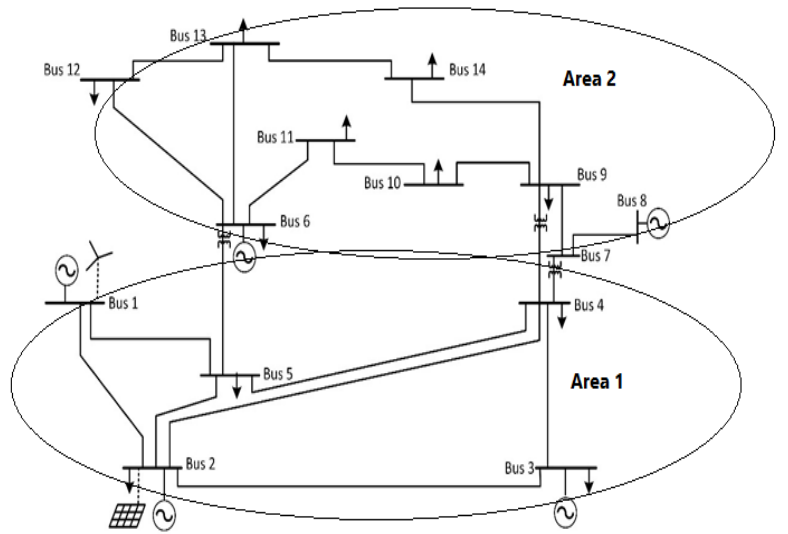

Figure 5: Single line diagram of the IEEE 14-bus system [21]

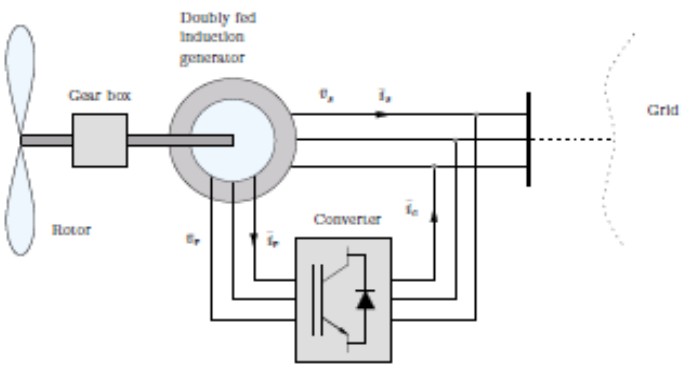

Fig.6: The DFIG with variable speed wind turbine [22]

The stator voltages are expressed as a function of the grid voltage magnitude, $v$, as:

$$
\begin{aligned}
& v_{d s}=-v \sin \theta \\
& v_{q s}=v \cos \theta
\end{aligned}
$$

The generator active, $p$, and reactive power, $q$, in terms of converter and stator currents are given by:

$$
\begin{aligned}
& p=v_{d s} i_{d s}+v_{q s} i_{q s}+v_{d c} i_{d c}+v_{q c} i_{q c} \\
& q=v_{q s} i_{d s}-v_{d s} i_{q s}+v_{q c} i_{d c}-v_{d c} i_{q c}
\end{aligned}
$$

Based on the converter state mode, the power delivered to the grid can be drawn as a function of stator and rotor currents. The converter powers on the grid side are:

$$
\begin{aligned}
& p_{c}=v_{d c} i_{d c}+v_{q c} i_{q c} \\
& q_{c}=v_{q c} i_{d c}-v_{d c} i_{q c}
\end{aligned}
$$

Assuming that the converter is an ideal model, the active power of the converter coincides with the rotor active 
power, thus, $p_{c}=p_{r}$. Therefore, the power delivered to the grid is

$p=v_{d s} i_{d s}+v_{q s} i_{q s}+v_{d r} i_{d r}+v_{q r} i_{q r}$

The generator equation of motion is modeled as a single shaft and hence, it can be written as:

$$
\begin{aligned}
& \dot{w}_{m}=\left(\tau_{m}-\tau_{e}\right) / 2 H_{m} \\
& \tau_{e}=\varphi_{d s} i_{q s}-\varphi_{q s} i_{d s} \\
& \tau_{e} \approx-\frac{x_{m} v i_{q r}}{w_{b}\left(x_{s}+x_{m}\right)}
\end{aligned}
$$

where $\tau_{e}$ and $w_{b}$ are electrical torque and system frequency rate $\mathrm{rad} / \mathrm{s}$, respectively. The $\varphi_{d s}$ and $\varphi_{q s}$ are stator fluxes in $d$ and $q$ axis.

The mechanical power, $p_{w}$, extracted from the wind farm is a function of the number of similar wind turbines, the wind speed, $v_{w}$, the rotor speed, $w_{m}$, and the pitch angle $\theta_{p}$. It can be approximated as follows:

$$
p_{w}=\frac{n_{g} \rho}{2 s_{n}} c_{p}\left(\lambda, \theta_{p}\right) A_{r} v_{w}^{3}
$$

where $n_{g}$ is the number of wind turbines that compose the farm, $\rho$ is the air density, $c_{p}$ is the power coefficient, $\lambda$ is the tip speed ratio and $A_{r}$ is the area swept by the rotor.

Data of the wind farm is depicted in Table 1. Both voltage and pitch angle control schemes are shown in Figs. 7 and 8, respectively. Real measured data is used for describing the wind speed as shown in Fig. 9.

\subsection{PV Model}

The output power of PV arrays $\left(P_{\text {out } P V}\right)$ is expressed as a a function of PV efficiency and solar radiation at time $t$ and is given by:

$$
p_{\text {out } P V}(t)=N_{P V} \cdot \eta_{P V} \cdot A \cdot I(t)
$$

where $N_{P V}, \eta_{P V}, A$, and $I(t)$ are the number of panels, efficiency of PV (\%), the area of PV array and solar radiation, respectively.

The PV is connected to the grid through inverter and transformer as shown in Fig. 10. The voltage components at the connected $\mathrm{AC}$ bus are:

$v_{d}=-v \sin \theta$ and $v_{q}=v \cos \theta$

The power injected into the AC bus is:

$p_{P V}=v_{d} i_{d}+v_{q} i_{q}$

\begin{tabular}{|c|c|}
\hline $\begin{array}{l}\text { Power, voltage and frequency ratings } \\
{[\mathrm{MVA}, \mathrm{kV}, \mathrm{Hz}]}\end{array}$ & {$\left[\begin{array}{lll}610 & 69 & 60\end{array}\right]$} \\
\hline $\begin{array}{l}\text { Stator resistance } r_{s} \text { and reactance } x_{s} \\
\text { [p.u. p.u.] }\end{array}$ & {$\left[\begin{array}{ll}0.01 & 0.10\end{array}\right]$} \\
\hline $\begin{array}{l}\text { Rotor resistance } r_{r} \text { and reactance } x_{r} \\
\text { [p.u. p.u.] }\end{array}$ & {$\left[\begin{array}{ll}0.01 & 0.08\end{array}\right]$} \\
\hline Magnetization reactance $x_{m}$ [p.u.] & 3.00 \\
\hline Inertia constants $H_{m}[\mathrm{kWs} / \mathrm{kVA}]$ & 3 \\
\hline Pitch control gain and time constant $\mathrm{k}_{\mathrm{p}}$, & {$\left[\begin{array}{ll}10 & 3\end{array}\right]$} \\
\hline $\mathrm{T}_{\mathrm{p}}$ [p.u. s] & \\
\hline Voltage control gain $\mathrm{K}_{\mathrm{V}}$ [p.u.] & 10 \\
\hline Power control time constant $\mathrm{T}_{\mathrm{e}}[\mathrm{s}]$ & 0.01 \\
\hline Number of poles $\mathrm{p}$ and gear box ratio & {$\left[\begin{array}{ll}4 & 1 / 89\end{array}\right]$} \\
\hline Blade length and number & {$\left[\begin{array}{lll}75.00 & 3\end{array}\right]$} \\
\hline Number of wind generators that & 30 \\
\hline
\end{tabular}

The data of the constant PV generator model is shown in Table 2 and the daily solar radiation curve is shown in Fig. $11[23]$.

Table 1: Wind farm data compose the park

\section{SIMULATION RESULTS}

The power system analysis toolbox, PSAT, is used to conduct the analysis in this work. Three different cases are emulated as mentioned above. The load flow and the proposed algorithm are applied to determine the appropriate size of the BESS.

Table 2: Data of solar PV plant

\begin{tabular}{lc}
\hline $\begin{array}{l}\text { Active power and voltage } \\
\text { rated (MW,PU) }\end{array}$ & {$\left[\begin{array}{ll}60 & 1.045\end{array}\right]$} \\
$\begin{array}{l}\text { Inverter response times } \\
\left(\mathrm{T}_{\mathrm{d}}, \mathrm{T}_{\mathrm{q}}\right)[\mathrm{s}, \mathrm{s}]\end{array}$ & {$\left[\begin{array}{ll}0.015 & 0.015\end{array}\right]$} \\
$\begin{array}{l}\text { Voltage PI controller } \\
\text { gains }\left(\mathrm{K}_{\mathrm{v}}, \mathrm{K}_{\mathrm{i}}\right)\end{array}$ & {$\left[\begin{array}{ll}0.08 & 50.9\end{array}\right]$} \\
$\begin{array}{l}\text { Number of modules and } \\
\text { output power of each unit }\end{array}$ & {$\left[\begin{array}{ll}3 & 10 \mathrm{MW}\end{array}\right]$} \\
\hline
\end{tabular}

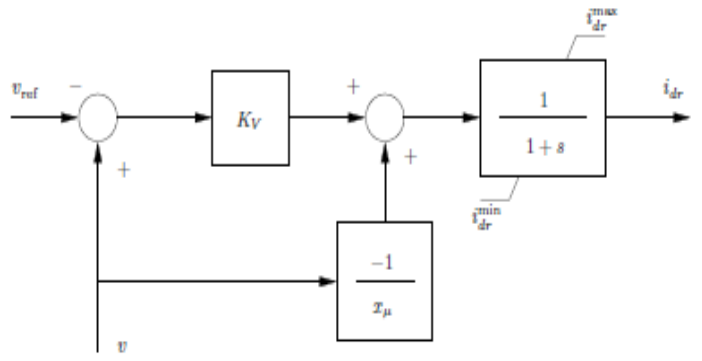

Figure 7: Voltage control scheme of the DFIG [24] 


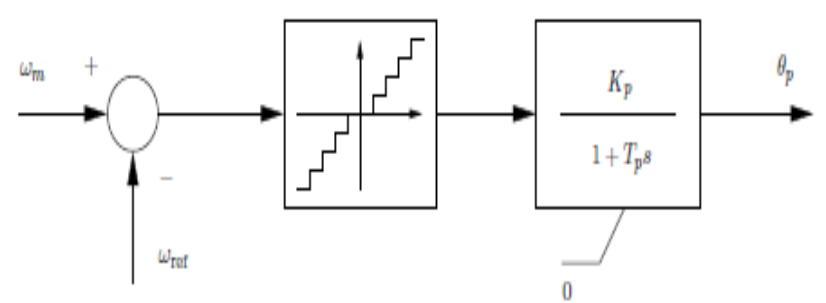

Figure 8: Pitch angle control scheme [24]

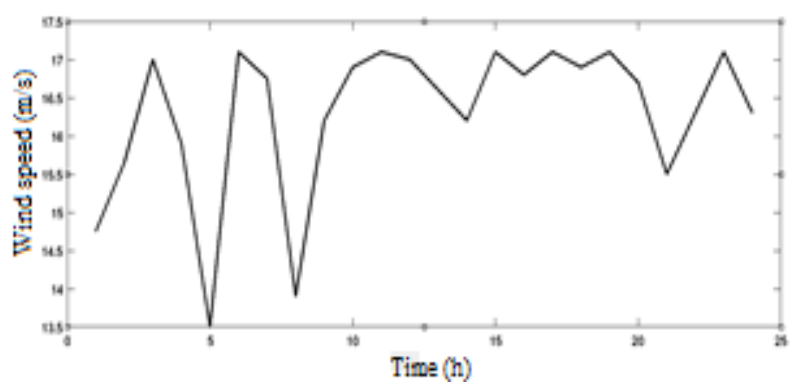

Figure 9: Wind speed through 24 hours

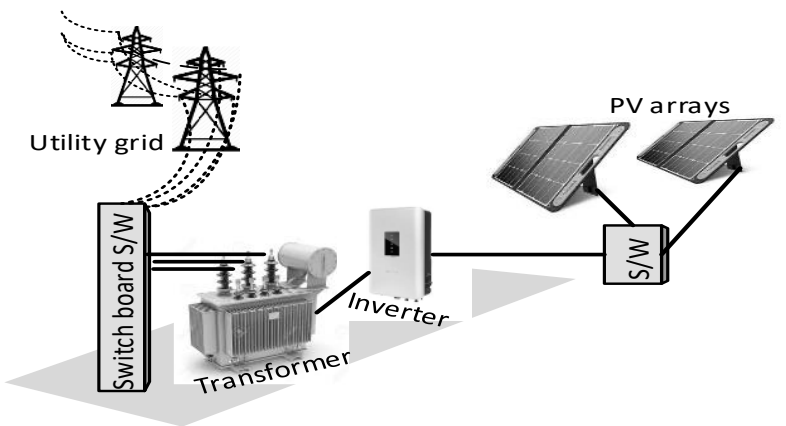

Figure 10: Grid-connected solar power generation

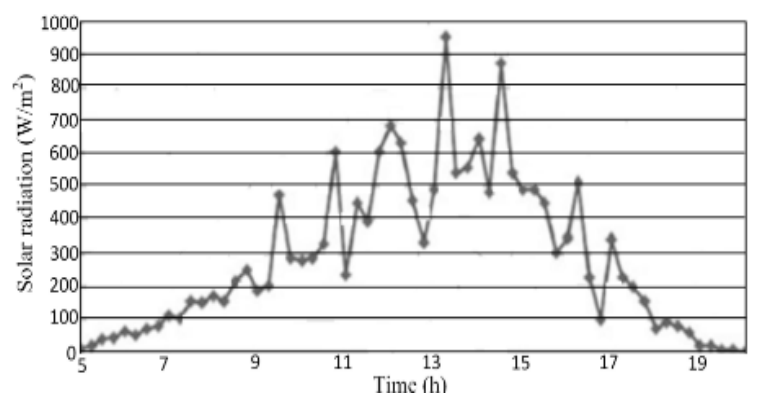

Figure 11: Solar radiation through day hours.

\subsection{Case \#1}

The conventional generator at bus \#1 is replaced by a wind farm with the same rated power. The traditional generator at bus \#1 operates at a leading power factor, thus absorbing reactive power from the grid. Therefore, the DFIG operates in sub mode at the leading power factor. The power extracted from the wind farm according to wind speed curve is depicted in Fig. 12.
According to the load flow algorithm, the battery power profile $\left(P_{\text {batt }}(t)\right)$ is obtained over 24 hours. From Fig. 13, $\Delta P$ has maximum positive and negative values at times equal 6 and 18 hours, respectively. As a sample of the results obtained by load flow calculations, the results of line flows at which $\Delta P$ is maximum positive and maximum negative, are selected and tabulated in Tables 3- 6 . Moreover, there is a shortage of battery power at $t$ equals an hour. For stable operation, it is necessary to prevent any shortage of battery power at any time. Therefore, the algorithm shown in Fig. 4 is applied to calculate the appropriate battery size and hence, the $S o C$ of the battery is drawn according to (6) as shown in Fig 14.

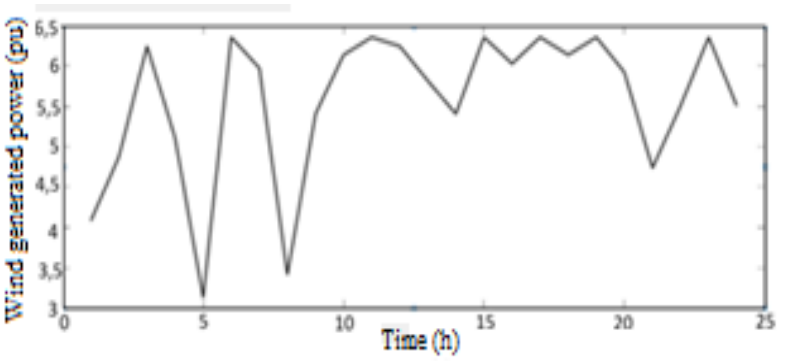

Figure 12: the wind generated power in respective to the speed variation

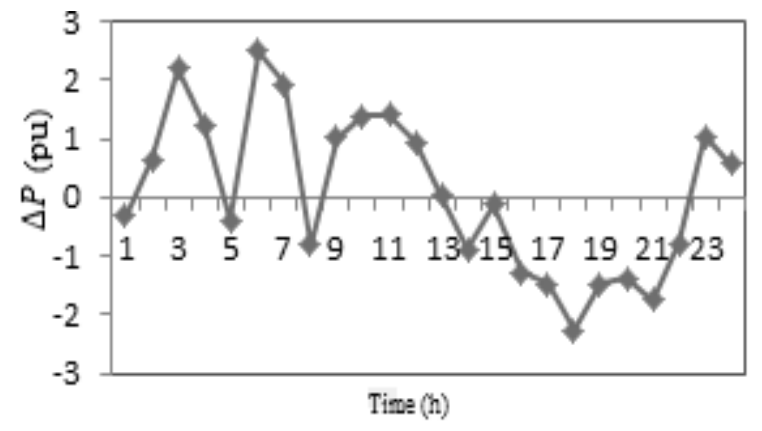

Figure 13: battery power profile for case \#1

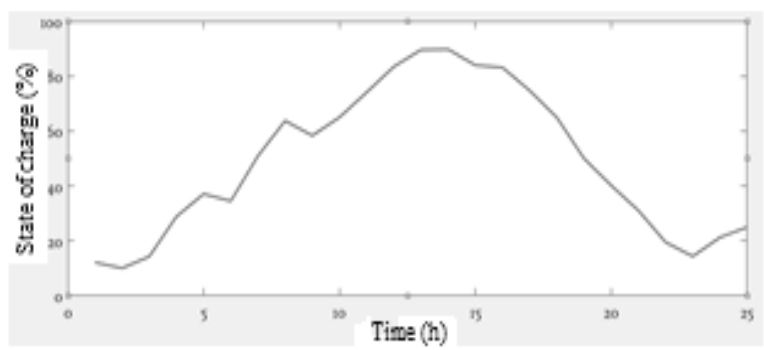

Figure 14: $S o C$ of the battery for case \#1 
Table 3: Line flows at $\left(t_{6}\right)$.

\begin{tabular}{|c|c|c|c|c|c|c|}
\hline $\begin{array}{l}\text { From } \\
\text { bus }\end{array}$ & $\begin{array}{l}\text { To } \\
\text { bus }\end{array}$ & $\begin{array}{l}\text { Line } \\
\#\end{array}$ & $P(\mathrm{pu})$ & $Q(\mathrm{pu})$ & $\begin{array}{l}P_{\text {Losses }} \\
(\mathrm{pu})\end{array}$ & $\begin{array}{l}Q_{\text {Losses }} \\
(\mathrm{pu})\end{array}$ \\
\hline 02 & 05 & 1 & 0.624 & 0.081 & 0.020 & 0.0280 \\
\hline 06 & 12 & 2 & 0.123 & 0.046 & 0.001 & 0.0038 \\
\hline 12 & 13 & 3 & 0.029 & 0.020 & 0.0002 & 0.0002 \\
\hline 06 & 13 & 4 & 0.281 & 0.147 & 0.0058 & 0.0114 \\
\hline 06 & 11 & 5 & 0.127 & 0.132 & 0.0028 & 0.0058 \\
\hline 11 & 10 & 6 & 0.072 & 0.101 & 0.0011 & 0.0027 \\
\hline 09 & 10 & 7 & 0.065 & 0.016 & 0.0001 & 0.0003 \\
\hline 09 & 14 & 8 & 0.130 & 0.004 & 0.0021 & 0.0044 \\
\hline 14 & 13 & 9 & 0.097 & -0.07 & 0.0025 & 0.0050 \\
\hline 07 & 09 & 10 & 0.409 & 0.228 & 0 & 0.0226 \\
\hline 01 & 02 & 11 & 2.664 & -0.42 & 0.125 & 0.3234 \\
\hline 03 & 02 & 12 & -1.08 & 0.177 & 0.0559 & 0.1896 \\
\hline 03 & 04 & 13 & -0.34 & 0.22 & 0.0114 & -0.0054 \\
\hline 01 & 05 & 14 & 1.202 & 0.115 & 0.0705 & 0.2388 \\
\hline 05 & 04 & 15 & 0.919 & 0.156 & 0.0116 & 0.02386 \\
\hline 02 & 04 & 16 & 0.846 & 0.059 & 0.0384 & 0.07783 \\
\hline 15 & 01 & 17 & $1 \mathrm{e}-05$ & -0.008 & 0 & 0.0083 \\
\hline 05 & 06 & 18 & 0.701 & 0.063 & 0 & 0.1087 \\
\hline 04 & 09 & 19 & 0.231 & 0.043 & 0 & 0.02939 \\
\hline 04 & 07 & 20 & 0.409 & -0.07 & 0 & 0.03484 \\
\hline 08 & 07 & 21 & 0 & 0.348 & 0 & 0.018 \\
\hline \multicolumn{7}{|c|}{ Table 4: Bus voltage and power at $\left(t_{6}\right)$. } \\
\hline $\begin{array}{l}\text { Bus } \\
\#\end{array}$ & $\begin{array}{l}\mathrm{V} \\
(\mathrm{pu})\end{array}$ & $\begin{array}{l}\text { phase } \\
\text { (rad) }\end{array}$ & $\begin{array}{l}\mathrm{P}_{\text {supply }} \\
\text { (pu) }\end{array}$ & $\begin{array}{l}\text { Qsupply }_{\text {su }} \\
\text { (pu) }\end{array}$ & $\begin{array}{l}\text { Pload } \\
(\mathrm{pu})\end{array}$ & $\begin{array}{l}\text { Qload } \\
(\mathrm{pu})\end{array}$ \\
\hline 01 & 1.06 & 0 & 6.035 & -0.278 & 2.4922 & 0 \\
\hline 02 & 1.045 & -0.149 & 0.4 & 1.077 & 0.328 & 0.1778 \\
\hline 03 & 1.01 & -0.363 & 0 & 0.670 & 1.4243 & 0.266 \\
\hline 04 & 0.994 & -0.289 & 0 & 0 & 0.7227 & 0.056 \\
\hline 05 & 0.999 & -0.248 & 0 & 0 & 0.1149 & 0.0224 \\
\hline 06 & 1.07 & -0.403 & 0 & 0.4789 & 0.1693 & 0.105 \\
\hline 07 & 1.033 & -0.371 & 0 & 0 & 0 & 0 \\
\hline 08 & 1.09 & -0.371 & 0 & 0.34915 & 0 & 0 \\
\hline 09 & 1.010 & -0.414 & 0 & 0 & 0.446 & 0.2324 \\
\hline 10 & 1.009 & -0.420 & 0 & 0 & 0.1361 & 0.0812 \\
\hline 11 & 1.034 & -0.414 & 0 & 0 & 0.0529 & 0.0252 \\
\hline 12 & 1.045 & -0.426 & 0 & 0 & 0.0922 & 0.0224 \\
\hline 13 & 1.034 & -0.427 & 0 & 0 & 0.204 & 0.0812 \\
\hline 14 & 0.993 & -0.448 & 0 & 0 & 0.2253 & 0.07 \\
\hline 15 & 1.045 & 0 & $1 \mathrm{e}-05$ & -0.0008 & 2.6 & 0 \\
\hline
\end{tabular}

\subsection{Case \#2}

The conventional generator at bus \#2 is replaced by a PV plant. The generator at bus \#2 supplies the system with reactive power as the PV plant cannot generate reactive power. Therefore, a capacitor bank is connected to the same bus to compensate of reactive power. The daily generated power corresponding to solar radiation curve is depicted in Fig. 15. The load flow algorithm is applied, and the power profile of the battery (Pbatt) is obtained as shown in Fig. 16.

Table 5: Line flows at $\left(t_{18}\right)$.

\begin{tabular}{|c|c|c|c|c|c|c|}
\hline $\begin{array}{l}\text { From } \\
\text { bus }\end{array}$ & $\begin{array}{l}\text { To } \\
\text { bus }\end{array}$ & $\begin{array}{l}\text { Line } \\
\#\end{array}$ & $\mathrm{P}(\mathrm{pu})$ & $\mathrm{Q}(\mathrm{pu})$ & $\begin{array}{l}\text { PLosses } \\
(\mathrm{pu})\end{array}$ & $\begin{array}{l}\text { QLosses } \\
(\mathrm{pu})\end{array}$ \\
\hline 02 & 05 & 1 & 1.206 & 0.3573 & 0.0833 & 0.2210 \\
\hline 06 & 12 & 2 & 0.231 & 0.0623 & 0.0061 & 0.0128 \\
\hline 12 & 13 & 3 & 0.054 & 0.0270 & 0.0007 & 0.0007 \\
\hline 06 & 13 & 4 & 0.5361 & 0.2103 & 0.0191 & 0.0377 \\
\hline 06 & 11 & 5 & 0.2448 & 0.2054 & 0.0084 & 0.0177 \\
\hline 11 & 10 & 6 & 0.1383 & 0.1625 & 0.0036 & 0.0085 \\
\hline 09 & 10 & 7 & 0.1179 & -0.071 & 0.0006 & 0.0017 \\
\hline 09 & 14 & 8 & 0.2406 & -0.013 & 0.0079 & 0.0168 \\
\hline 14 & 13 & 9 & -0.184 & -0.100 & 0.0085 & 0.0173 \\
\hline 07 & 09 & 10 & 0.7612 & 0.2836 & 0 & 0.0735 \\
\hline 01 & 02 & 11 & 5.994 & -0.666 & 0.6268 & 1.8554 \\
\hline 03 & 02 & 12 & -2.072 & 0.7969 & 0.2287 & 0.9175 \\
\hline 03 & 04 & 13 & -0.565 & 0.7337 & 0.0580 & 0.1155 \\
\hline 01 & 05 & 14 & 2.404 & 0.6011 & 0.2970 & 1.177 \\
\hline 05 & 04 & 15 & 1.691 & -0.405 & 0.0462 & 0.1346 \\
\hline 02 & 04 & 16 & 1.652 & 0.325 & 0.1516 & 0.4234 \\
\hline 15 & 01 & 17 & 2.261 & -0.001 & 0 & 0.1334 \\
\hline 05 & 06 & 18 & 1.326 & -0.056 & 0 & 0.4420 \\
\hline 04 & 09 & 19 & 0.4233 & 0.0467 & 0 & 0.1091 \\
\hline 04 & 07 & 20 & 0.7612 & -0.122 & 0 & 0.1369 \\
\hline 08 & 07 & 21 & 0 & 0.5958 & 0 & 0.0526 \\
\hline
\end{tabular}

Table 6: Bus voltage and power at $\left(t_{18}\right)$.

\begin{tabular}{lllllrl}
\hline $\begin{array}{l}\text { Bus } \\
\#\end{array}$ & $\begin{array}{l}\text { V } \\
(\mathrm{pu})\end{array}$ & $\begin{array}{l}\text { Phase } \\
(\mathrm{rad})\end{array}$ & $\begin{array}{l}\mathrm{P}_{\text {supply }} \\
(\mathrm{pu})\end{array}$ & $\begin{array}{l}\mathrm{Q}_{\text {supply }} \\
(\mathrm{pu})\end{array}$ & $\begin{array}{l}\mathrm{P}_{\text {load }} \\
(\mathrm{pu})\end{array}$ & $\begin{array}{l}\mathrm{Q}_{\text {load }} \\
(\mathrm{pu})\end{array}$ \\
\hline 01 & 1.06 & 0 & 6.138 & -0.224 & 0 & 0 \\
02 & 1.045 & -0.3377 & 0.4 & 3.503 & 0.607 & 0.1778 \\
03 & 1.01 & -0.7769 & 0 & 0.6707 & 2.637 & 0.266 \\
04 & 0.931 & -0.6200 & 0 & 0 & 1.338 & 0.056 \\
05 & 0.934 & -0.5319 & 0 & 0 & 0.212 & 0.0224 \\
06 & 1.07 & -0.8489 & 0 & 0.4789 & 0.313 & 0.105 \\
07 & 0.993 & -0.7890 & 0 & 0 & 0 & 0 \\
08 & 1.09 & -0.7890 & 0 & 0.3491 & 0 & 0 \\
09 & 0.965 & -0.8763 & 0 & 0 & 0.826 & 0.2324 \\
10 & 0.968 & -0.8894 & 0 & 0 & 0.252 & 0.0812 \\
11 & 1.010 & -0.8759 & 0 & 0 & 0.098 & 0.0252 \\
12 & 1.029 & -0.8957 & 0 & 0 & 0.1708 & 0.0224 \\
13 & 1.012 & -0.9005 & 0 & 0 & 0.378 & 0.0812 \\
14 & 0.940 & -0.9499 & 0 & 0 & 0.4172 & 0.07 \\
15 & 1.045 & 0.05534 & 2.261 & -0.001 & 0 & 0 \\
\hline
\end{tabular}

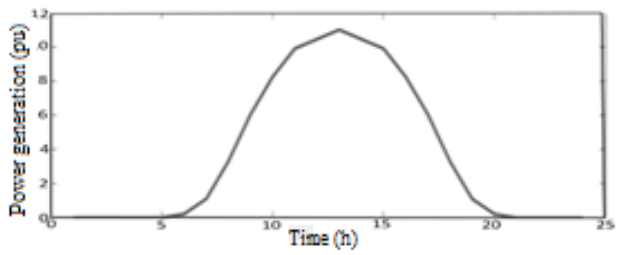

Figure 15: PV power vs. day hours. 


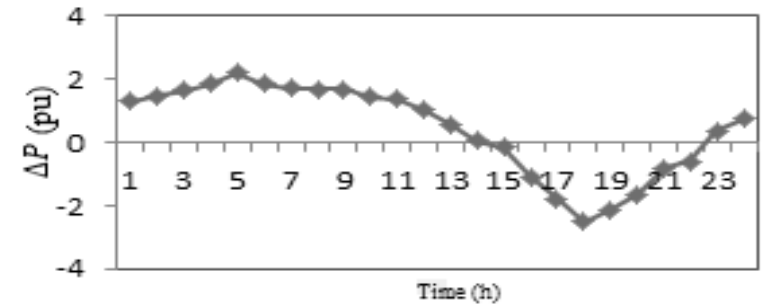

Figure 16: battery power profile for case \#2

From the power profile, it is found that the maximum and minimum values of $\Delta P$ are at times equal 5 and 18 hours, respectively. The results of line flows at which $\Delta P$ is maximum positive and maximum negative are chosen and tabulated in Tables 7- 10. The proposed algorithm is applied to adjust the battery size while (6) is used to find the battery $S o C$ values as shown in Fig. 17.

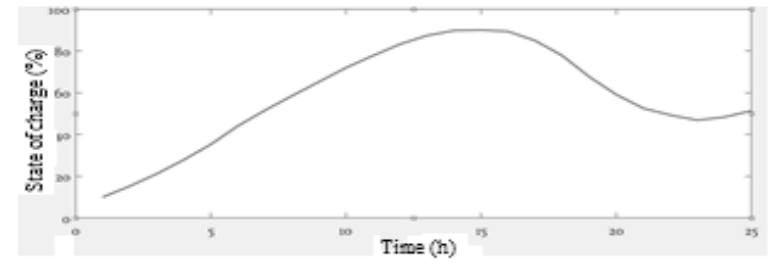

Figure 17: The $\mathrm{SoC}$ of the battery for case \#2

Table 7: Line flows at $\left(t_{5}\right)$

\begin{tabular}{lllllll}
\hline $\begin{array}{l}\text { From } \\
\text { bus }\end{array}$ & $\begin{array}{l}\text { To } \\
\text { bus }\end{array}$ & $\begin{array}{l}\text { Line } \\
\#\end{array}$ & $\mathrm{P}(\mathrm{pu})$ & $\mathrm{Q}(\mathrm{pu})$ & $\begin{array}{l}\text { PLosses } \\
(\mathrm{pu})\end{array}$ & $\begin{array}{l}\text { QLosses } \\
(\mathrm{pu})\end{array}$ \\
\hline 02 & 05 & 1 & 0.370 & 0.145 & 0.008 & -0.009 \\
06 & 12 & 2 & 0.115 & 0.045 & 0.001 & 0.003 \\
12 & 13 & 3 & 0.028 & 0.019 & 0.002 & 0.002 \\
06 & 13 & 4 & 0.264 & 0.144 & 0.005 & 0.010 \\
06 & 11 & 5 & 0.127 & 0.127 & 0.002 & 0.005 \\
11 & 10 & 6 & 0.075 & 0.097 & 0.001 & 0.002 \\
09 & 10 & 7 & 0.051 & -0.012 & $9 \mathrm{e}-05$ & 0.002 \\
09 & 14 & 8 & 0.114 & 0.005 & 0.001 & 0.003 \\
14 & 13 & 9 & -0.09 & -0.067 & 0.002 & 0.004 \\
07 & 09 & 10 & 0.369 & 0.227 & 0 & 0.019 \\
01 & 02 & 11 & 4.937 & -0.657 & 0.427 & 1.246 \\
03 & 02 & 12 & -0.93 & 0.109 & 0.041 & 0.127 \\
03 & 04 & 13 & -0.382 & 0.236 & 0.013 & 0.0005 \\
01 & 05 & 14 & 1.583 & 0.137 & 0.121 & 0.450 \\
05 & 04 & 15 & 1.052 & -0.23 & 0.015 & 0.036 \\
02 & 04 & 16 & 0.629 & 0.094 & 0.021 & 0.027 \\
15 & 01 & 17 & -2.22 & 0.006 & 0 & 0.012 \\
05 & 06 & 18 & 0.6639 & 0.056 & 0 & 0.097 \\
04 & 09 & 19 & 0.209 & 0.041 & 0 & 0.024 \\
04 & 07 & 20 & 0.369 & -0.068 & 0 & 0.0285 \\
08 & 07 & 21 & 0 & 0.341 & 0 & 0.01724 \\
\hline & & & & & &
\end{tabular}

\subsection{Case \#3}

The conventional generators at buses \#1 and \#2 are replaced by wind farm and PV plant, respectively. Applying the load flow analysis with the same data given in the first and second cases, the power profile of the battery $\left(P_{\text {batt }}\right)$ is obtained as depicted in Fig. 18.

Table 8: Bus voltage and power at $\left(t_{5}\right)$

\begin{tabular}{lllllrr}
\hline $\begin{array}{l}\text { Bus } \\
\#\end{array}$ & $\begin{array}{l}\text { V } \\
(\mathrm{pu})\end{array}$ & $\begin{array}{l}\text { Phase } \\
(\mathrm{rad})\end{array}$ & $\begin{array}{l}\mathrm{P}_{\text {supply }} \\
(\mathrm{pu})\end{array}$ & $\begin{array}{l}\mathrm{Q}_{\text {supply }} \\
(\mathrm{pu})\end{array}$ & $\begin{array}{l}\text { Pload } \\
(\mathrm{pu})\end{array}$ & $\begin{array}{l}\mathrm{Q}_{\text {load }} \\
(\mathrm{pu})\end{array}$ \\
\hline 01 & 1.06 & 0 & 6.1520 & -0.224 & 0 & 0 \\
02 & 1.045 & -0.278 & 0.0001 & 2.345 & 0.303 & 0.177 \\
03 & 1.01 & -0.460 & 0 & 0.6707 & 1.318 & 0.266 \\
04 & 0.99 & -0.378 & 0 & 0 & 0.669 & 0.056 \\
05 & 0.99 & -0.331 & 0 & 00 & 0.106 & 0.022 \\
06 & 1.07 & -0.477 & 0 & 0.4789 & 0.106 & 0.105 \\
07 & 1.03 & -0.452 & 0 & 0 & 0 & 0 \\
08 & 1.09 & -0.452 & 0 & 0.3491 & 0 & 0 \\
09 & 1.01 & -0.491 & 0 & 0 & 0.413 & 0.232 \\
10 & 1.011 & -0.495 & 0 & 0 & 0.126 & 0.081 \\
11 & 1.035 & -0.489 & 0 & 0 & 0.049 & 0.025 \\
12 & 1.04 & -0.498 & 0 & 0 & 0.085 & 0.022 \\
13 & 1.03 & -0.499 & 0 & 0 & 0.189 & 0.081 \\
14 & 0.996 & -0.521 & 0 & 0 & 0.208 & 0.07 \\
15 & 1.045 & -0.283 & $1 \mathrm{e}-05$ & 0.00618 & 2.129 & 0 \\
\hline
\end{tabular}

Table 9: Line flows at $\left(t_{18}\right)$

\begin{tabular}{|c|c|c|c|c|c|c|}
\hline $\begin{array}{l}\text { From } \\
\text { bus }\end{array}$ & $\begin{array}{l}\text { To } \\
\text { bus }\end{array}$ & $\begin{array}{l}\text { Line } \\
\#\end{array}$ & $\mathrm{P}(\mathrm{pu})$ & $\mathrm{Q}(\mathrm{pu})$ & $\begin{array}{l}\text { PLosses } \\
(\mathrm{pu})\end{array}$ & $\begin{array}{l}\text { QLosses } \\
(\mathrm{pu})\end{array}$ \\
\hline 20 & 05 & 1 & 1.375 & 0.299 & 0.103 & 0.283 \\
\hline 06 & 12 & 2 & 0.230 & 0.062 & 0.006 & 0.012 \\
\hline 12 & 13 & 3 & 0.053 & 0.027 & 0.0007 & 0.006 \\
\hline 06 & 13 & 4 & 0.532 & 0.209 & 0.018 & 0.037 \\
\hline 06 & 11 & 5 & 0.237 & 0.203 & 0.008 & 0.017 \\
\hline 11 & 10 & 6 & 0.131 & 0.161 & 0.003 & 0.008 \\
\hline 09 & 10 & 7 & 0.124 & -0.070 & 0.0007 & 0.001 \\
\hline 09 & 14 & 8 & 0.245 & -0.013 & 0.0081 & 0.01 \\
\hline 14 & 13 & 9 & 0.180 & -0.100 & 0.008 & 0.016 \\
\hline 07 & 09 & 10 & 0.768 & 0.283 & 0 & 0.074 \\
\hline 01 & 02 & 11 & 3.70 & 0.567 & 0.241 & 0.678 \\
\hline 03 & 02 & 12 & -2.11 & 0.831 & 0.239 & 0.963 \\
\hline 03 & 04 & 13 & 0.521 & 0.6 & 0.050 & 0.095 \\
\hline 01 & 05 & 14 & 2.006 & 0.467 & 0.205 & 0.7981 \\
\hline 05 & 04 & 15 & 1.545 & -0.302 & 0.037 & 0.106 \\
\hline 02 & 04 & 16 & 1.77 & 0.30 & 0.172 & 0.486 \\
\hline 15 & 01 & 17 & 2.469 & 0.006 & 0 & 0.0151 \\
\hline 05 & 06 & 18 & 1.314 & -0.034 & 0 & 0.4269 \\
\hline 04 & 09 & 19 & 0.427 & 0.050 & 0 & 0.110 \\
\hline 04 & 07 & 20 & 0.768 & -0.112 & 0 & 0.137 \\
\hline 08 & 07 & 21 & 0 & 0.584 & 0 & 0.050 \\
\hline
\end{tabular}




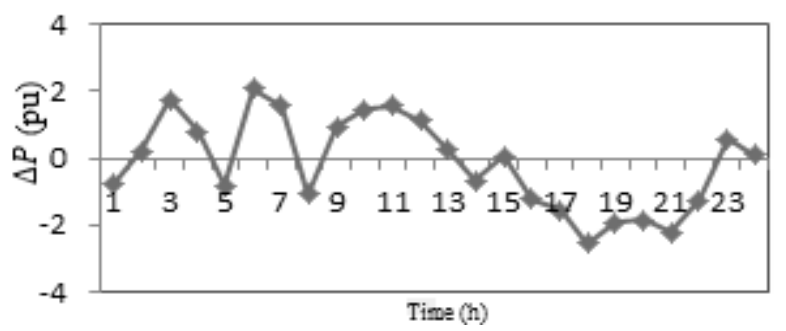

Figure18: battery power profile of case $\# 3$

Table 10: Bus voltage and power at $\left(t_{18}\right)$

\begin{tabular}{lllllll}
\hline $\begin{array}{l}\text { Bus } \\
\#\end{array}$ & $\begin{array}{l}\mathrm{V} \\
(\mathrm{pu})\end{array}$ & $\begin{array}{l}\text { Phase } \\
(\mathrm{rad})\end{array}$ & $\begin{array}{l}\mathrm{P}_{\text {supply }} \\
(\mathrm{pu})\end{array}$ & $\begin{array}{l}\mathrm{Q}_{\text {supply }} \\
(\mathrm{pu})\end{array}$ & $\begin{array}{l}\mathrm{P}_{\text {load }} \\
(\mathrm{pu})\end{array}$ & $\begin{array}{l}\mathrm{Q}_{\text {load }} \\
(\mathrm{pu})\end{array}$ \\
\hline 01 & 1.06 & 0 & 6.1582 & -0.224 & 0 & 0 \\
02 & 1.04 & -0.208 & 0.18 & 2.163 & 0.607 & 0.177 \\
03 & 1.01 & -0.658 & 0 & 0.6707 & 2.637 & 0.266 \\
04 & 0.93 & -0.513 & 0 & 0 & 1.338 & 0.056 \\
05 & 0.94 & -0.435 & 0 & 0 & 0.212 & 0.022 \\
06 & 1.07 & -0.746 & 0 & 0.4789 & 0.313 & 0.105 \\
07 & 0.99 & -0.683 & 0 & 0 & 0 & 0 \\
08 & 1.09 & -0.683 & 0 & 0.3491 & 0 & 0 \\
09 & 0.96 & -0.771 & 0 & 0 & 0.826 & 0.232 \\
10 & 0.97 & -0.7847 & 0 & 0 & 0.252 & 0.081 \\
11 & 1.01 & -0.772 & 0 & 0 & 0.098 & 0.025 \\
12 & 1.02 & 0.793 & 0 & 0 & 0.1708 & 0.022 \\
13 & 1.01 & -0.797 & 0 & 0 & 0.378 & 0.081 \\
14 & 0.94 & -0.845 & 0 & 0 & 0.417 & 0.07 \\
15 & 1.04 & -0.202 & 2.106 & -0.001 & 0 & 0 \\
\hline
\end{tabular}

It is observed that the maximum and minimum values of $\Delta P$ occur at times equal 6 and 18 hours, respectively and the corresponding line flows are tabulated in Tables 11-14. Fig. 19 shows the $\mathrm{SoC}$ of the battery using the same procedure.

Table 11: Line flows at $\left(t_{6}\right)$

\begin{tabular}{lllllll}
\hline $\begin{array}{l}\text { From } \\
\text { Bus }\end{array}$ & $\begin{array}{l}\text { To } \\
\text { Bus }\end{array}$ & $\begin{array}{l}\text { Line } \\
2\end{array}$ & P $(\mathrm{pu})$ & $\mathrm{Q}(\mathrm{pu})$ & $\begin{array}{l}\mathrm{P}_{\text {losses }} \\
(\mathrm{pu})\end{array}$ & $\begin{array}{l}\mathrm{Q}_{\text {losses }} \\
(\mathrm{pu})\end{array}$ \\
\hline 6 & 12 & 2 & 0.59 & 0.090 & 0.019 & 0.022 \\
12 & 13 & 3 & 0.12 & 0.046 & 0.002 & 0.003 \\
6 & 13 & 4 & 0.28 & 0.020 & 0.001 & 0.001 \\
6 & 11 & 5 & 0.12 & 0.132 & 0.005 & 0.011 \\
11 & 10 & 6 & 0.07 & 0.100 & 0.001 & 0.006 \\
9 & 10 & 7 & 0.064 & -0.016 & 0.001 & 0.002 \\
9 & 14 & 8 & 0.12 & 0.004 & 0.002 & 0.004 \\
14 & 13 & 9 & -0.09 & -0.069 & 0.002 & 0.005 \\
7 & 9 & 10 & 0.40 & 0.228 & 0 & 0.022 \\
1 & 2 & 11 & 3.02 & -0.480 & 0.161 & 0.433 \\
3 & 2 & 12 & -1.07 & 0.173 & 0.054 & 0.185 \\
3 & 4 & 13 & -0.34 & 0.231 & 0.012 & -0.003 \\
1 & 5 & 14 & 1.271 & 0.118 & 0.078 & 0.272 \\
5 & 4 & 15 & 0.94 & -0.170 & 0.012 & 0.026 \\
2 & 4 & 16 & 0.824 & 0.064 & 0.036 & 0.071 \\
15 & 1 & 17 & $1 \mathrm{e}-0$ & -0.008 & 0 & 0.008 \\
5 & 6 & 18 & 0.70 & 0.061 & 0 & 0.109 \\
4 & 9 & 19 & 0.23 & 0.043 & 0 & 0.029 \\
4 & 7 & 20 & 0.40 & -0.067 & 0 & 0.034 \\
8 & 7 & 21 & 0 & 0.349 & 0 & 0.018 \\
\hline
\end{tabular}

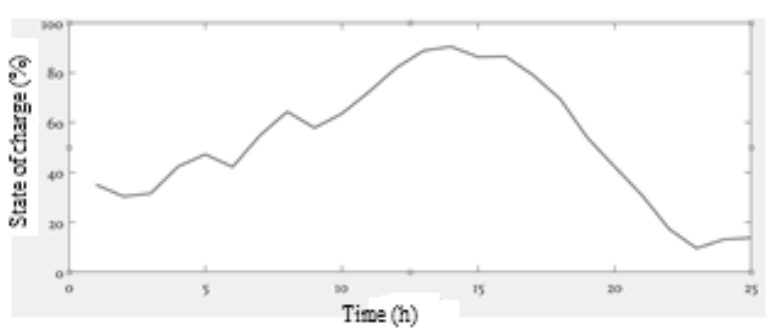

Figure19: The $S o C$ of the battery case \#3

According to the analysis of steady state condition and the different cases conducted above, the algorithm plays an important role in determining the initial value of the battery by finding the breaking value at a certain time, which is defined as the power that the battery must have to compensate the lack of power. Therefore, one breaking value is found at case 1 , which equals $0.3172 \mathrm{pu}$. In the second case, no breaking values are existed. On the contrary, in the third case, three breaking values are found, which are 0.766, 2.1455, and 1.2492 pu. From the results, it is expected that the third case will have the highest initial value of the battery size as shown in Table 15 . In addition, the results of the battery size according to the applied algorithm are scheduled in Table 15. It is found that the highest size of the battery is at case 2 while the first case has the lowest size.

Table 12: Bus voltage and power at $\left(t_{6}\right)$

\begin{tabular}{|c|c|c|c|c|c|c|}
\hline $\begin{array}{c}\text { Bus } \\
\#\end{array}$ & $\mathrm{~V}(\mathrm{pu})$ & $\begin{array}{l}\text { Phase } \\
\text { (rad) }\end{array}$ & $\begin{array}{l}\text { Psupply } \\
(\mathrm{pu})\end{array}$ & $\begin{array}{c}\text { Qsupply } \\
\text { (pu) }\end{array}$ & $\begin{array}{c}\text { Pload } \\
(\mathrm{pu})\end{array}$ & $\begin{array}{l}\text { Q load } \\
\text { (pu) }\end{array}$ \\
\hline 01 & 1.06 & 0 & 6.0998 & -0.278 & 2.492 & 0 \\
\hline 02 & 1.045 & -0.170 & 0.012 & 1.0775 & 0.328 & 0.177 \\
\hline 03 & 1.01 & -0.382 & 0 & 0.670 & 1.424 & 0.266 \\
\hline 04 & 0.993 & -0.305 & 0 & 0 & 0.722 & 0.056 \\
\hline 05 & 0.998 & -0.263 & 0 & 0 & 0.114 & 0.022 \\
\hline 06 & 1.07 & -0.418 & 0 & 0.4789 & 0.169 & 0.105 \\
\hline 07 & 1.033 & -0.387 & 0 & 0 & 0 & 0 \\
\hline 08 & 1.09 & -0.387 & 0 & 0.34915 & 0 & 0 \\
\hline 09 & 1.01 & -0.430 & 0 & 0 & 0.446 & 0.232 \\
\hline 10 & 1.001 & -0.436 & 0 & 0 & 0.136 & 0.081 \\
\hline 11 & 1.03 & -0.430 & 0 & 0 & 0.052 & 0.025 \\
\hline 12 & 1.045 & -0.441 & 0 & 0 & 0.092 & 0.022 \\
\hline 13 & 1.03 & -0.442 & 0 & 0 & 0.204 & 0.081 \\
\hline 14 & 0.993 & -0.464 & 0 & 0 & 0.225 & 0.07 \\
\hline 15 & 1.045 & 0 & $1 \mathrm{e}-05$ & -0.0005 & 2.002 & 0 \\
\hline
\end{tabular}

Table 13: Line flows at $\left(t_{18}\right)$

\begin{tabular}{lllllll}
\hline $\begin{array}{l}\text { From } \\
\text { Bus }\end{array}$ & $\begin{array}{l}\text { To } \\
\text { Bus }\end{array}$ & $\begin{array}{l}\text { Line } \\
\#\end{array}$ & $\mathrm{P}(\mathrm{pu})$ & $\mathrm{Q} \mathrm{pu})$ & $\begin{array}{l}\mathrm{P}_{\text {losses }} \\
(\mathrm{pu})\end{array}$ & $\begin{array}{l}\text { Qlosses } \\
(\mathrm{pu})\end{array}$ \\
\hline 2 & 5 & 1 & 1.19 & 0.36 & 0.081 & 0.215 \\
6 & 12 & 2 & 0.231 & 0.06 & 0.006 & 0.012 \\
12 & 13 & 3 & 0.05 & 0.027 & 0.001 & 0.001 \\
6 & 13 & 4 & 0.536 & 0.21 & 0.019 & 0.037 \\
6 & 11 & 5 & 0.24 & 0.205 & 0.008 & 0.017 \\
11 & 10 & 6 & 0.139 & 0.162 & 0.003 & 0.008 \\
9 & 10 & 7 & 0.117 & -0.07 & 0.001 & 0.002 \\
\hline
\end{tabular}




\begin{tabular}{lllllll}
\hline 9 & 14 & 8 & 0.240 & -0.013 & 0.01 & 0.016 \\
14 & 13 & 9 & -0.18 & -0.10 & 0.008 & 0.017 \\
7 & 9 & 10 & 0.760 & 0.283 & 0 & 0.073 \\
1 & 2 & 11 & 6.23 & -0.66 & 0.67 & 2.007 \\
3 & 2 & 12 & -2.06 & 0.79 & 0.22 & 0.913 \\
3 & 4 & 13 & -0.56 & 0.739 & 0.05 & 0.117 \\
1 & 5 & 14 & 2.44 & 0.617 & 0.30 & 1.220 \\
5 & 4 & 15 & 1.70 & -0.41 & 0.047 & 0.137 \\
2 & 4 & 16 & 1.640 & 0.328 & 0.149 & 0.417 \\
15 & 1 & 17 & 2.481 & -0.003 & 0 & 0.159 \\
5 & 6 & 18 & 1.32 & -0.05 & 0 & 0.443 \\
4 & 9 & 19 & 0.42 & 0.046 & 0 & 0.109 \\
4 & 7 & 20 & 0.760 & -0.123 & 0 & 0.136 \\
8 & 7 & 21 & 0 & 0.597 & 0 & 0.052 \\
\hline
\end{tabular}

Table 14: Bus voltage and power at $\left(t_{18}\right)$

\begin{tabular}{lllllll}
\hline $\begin{array}{l}\text { Bus } \\
\#\end{array}$ & $V(\mathrm{pu})$ & $\begin{array}{l}\text { Phase } \\
(\mathrm{rad})\end{array}$ & $\begin{array}{l}\mathrm{P}_{\text {supply }}(\mathrm{pu}) \\
01\end{array}$ & $\begin{array}{l}\mathrm{Q}_{\text {supply }} \\
(\mathrm{pu})\end{array}$ & $\begin{array}{l}\mathrm{P}_{\text {load }} \\
(\mathrm{pu})\end{array}$ & $\begin{array}{l}\text { Qload } \\
(\mathrm{pu})\end{array}$ \\
\hline 02 & 1.045 & -0 & 6.19 & -0.224 & 0 & 0 \\
03 & 1.01 & -0.78 & 0.18 & 2.163 & 0.60 & 0.17 \\
04 & 0.931 & -0.63 & 0 & 0.670 & 2.63 & 0.266 \\
05 & 0.933 & -0.54 & 0 & 0 & 1.33 & 0.056 \\
06 & 1.07 & -0.85 & 0 & 0.47 & 0.21 & 0.02 \\
07 & 0.993 & -0.80 & 0 & 0 & 0 & 0.105 \\
08 & 1.09 & -0.80 & 0 & 0.349 & 0 & 0 \\
09 & 0.965 & -0.88 & 0 & 0 & 0.826 & 0.23 \\
10 & 0.968 & -0.90 & 0 & 0 & 0.252 & 0.081 \\
11 & 1.010 & -0.88 & 0 & 0 & 0.098 & 0.025 \\
12 & 1.029 & -0.90 & 0 & 0 & 0.170 & 0.022 \\
13 & 1.012 & -0.91 & 0 & 0 & 0.378 & 0.081 \\
14 & 0.940 & -0.96 & 0 & 0 & 0.41 & 0.07 \\
15 & 1.045 & 0.0607 & 2.01 & -0.001 & 0 & 0 \\
\hline
\end{tabular}

Table 15: the initial battery value and its size for each case

\begin{tabular}{lcc}
\hline Cases & $\begin{array}{c}\text { Initial value } \\
{[\%]}\end{array}$ & $\begin{array}{c}\text { Battery size } \\
{[\mathrm{MWh}]}\end{array}$ \\
\hline Case \#1 & 12.097 & 36,300 \\
Case \#2 & 10 & 59,664 \\
Case \#3 & 35.1 & 39,576 \\
\hline
\end{tabular}

\section{CONCLUSION}

This paper has analyzed the effect of replacing the traditional generator by RERs on the power system operation. Due to the variability of RERs, the ESSs are proposed as a solution to ensure the balance between generation and demand. It is the suitable manner to meet the long-term energy demand. To emphasis the correct operation, the sizing of the battery is an important decision that should be taken carefully. The load flow algorithm is used to get the surplus and shortage powers of the power system during a day. Then, once the battery power profile is obtained from load flow algorithm, the proposed algorithm is applied to efficiently adjust the battery size and its initial value. Three cases are conducted, and the simulation results show the important role of the proposed algorithm for keeping the reliability of the power system.

$\begin{array}{cl}\text { Abbreviations } & \\ \text { RERs } & \text { Renewable energy resources } \\ \text { ESDs } & \text { Energy storage devices } \\ \text { PSAT } & \text { Power system analysis toolbox } \\ \text { BESS } & \text { Battery energy storage system } \\ \text { ESS } & \text { Energy storage system } \\ \text { PV } & \text { Photo voltaic } \\ \text { DFIG } & \text { Doubly fed induction generator }\end{array}$

$\begin{array}{cl}\text { Nomenclature } & \\ p_{c} & \text { Active power of the converter } \\ p_{r} & \text { Rotor active power } \\ \tau_{e} & \text { Electrical torque } \\ w_{b} & \text { System frequency rate } \\ \varphi_{d s} \text { and } \varphi_{q s} & \text { Stator fluxes in } d \text { and } q \text { axis } \\ p_{w} & \text { Mechanical power } \\ v_{w} & \text { Wind speed } \\ \theta_{p} & \text { Pitch angle } \\ n_{g} & \text { Number of wind turbines } \\ \rho & \text { Air density } \\ c_{p} & \text { Power coefficient } \\ \lambda & \text { Tip speed ratio } \\ A_{r} & \text { Area swept by the rotor } \\ H_{m} & \text { Inertia constant of wind } \\ P_{\text {out } P V} & \text { Output power of PV } \\ N_{P V} & \text { Number of panels } \\ \eta_{P V} & \text { Efficiency of PV (\%) } \\ A & \text { Area of PV array } \\ I(t) & \text { Solar radiation } \\ P_{l o s s e s} & \text { System losses } \\ P_{G e n} & \text { Total power generation } \\ P_{E S S} & \text { Power of the energy storage system } \\ S o C & \text { State of Charge } \\ S o C_{i n t} & \text { Initial SoC of ESS } \\ \eta_{d} & \text { Discharging efficiency } \\ \eta_{c} & \text { Charging efficiency } \\ & \end{array}$

\section{Credit Authorship Contribution Statement}

Mahmoud M. Mashaa1: Methodology, Software, Data Curation, Writing, Azza A. ElDesouky: Validation, Writing - Review, Original draft, Supervision,

Abdelhay A. Sallam: Conceptualization, Review \& Editing

\section{Declaration of Competing Interest}

The authors declare that they have no known competing financial interests or personal relationships that could have appeared to influence the work reported in this paper.

\section{References}

[1] E. M. Ali and A. A. ElDesouky, "Implementation of Boolean PSO for Service Restoration Using Distribution Network Reconfiguration Simultaneously With 
Distributed Energy Resources and Capacitor Banks," International Journal of Renewable Energy Research (IJRER), vol. 10, pp. 354-365, 2020.

[2] M. F. Akorede, H. Hizam, and E. Pouresmaeil, "Distributed energy resources and benefits to the environment," Renewable and sustainable energy reviews, vol. 14, pp. 724-734, 2010.

[3] Y. V. Makarov, C. Loutan, J. Ma, P. De Mello, and S. $\mathrm{Lu}$, "Impacts of integration of wind generation on regulation and load following requirements of California power systems," in 2008 5th International Conference on the European Electricity Market, 2008, pp. 1-6.

[4] Y. V. Makarov, S. Lu, N. Samaan, Z. Huang, K. Subbarao, P. V. Etingov, J. Ma, R. P. Hafen, R. Diao, and $\mathrm{N}$. Lu, "Integration of uncertainty information into power system operations," in 2011 IEEE Power and Energy Society General Meeting, 2011, pp. 1-13.

[5] A. Pina, C. A. Silva, and P. Ferrão, "High-resolution modeling framework for planning electricity systems with high penetration of renewables," Applied Energy, vol. 112, pp. 215-223, 2013.

[6] A. Purvins, A. Zubaryeva, M. Llorente, E. Tzimas, and A. Mercier, "Challenges and options for a large wind power uptake by the European electricity system," Applied Energy, vol. 88, pp. 1461-1469, 2011.

[7] E. Tzimas, R. Moss, and P. Ntagia, "Technology Map of the European Strategic Energy Technology Plan (SETPlan)," JRC Scientific and Technical Reports, Luxembourg, 2011.

[8] F. Iov, M. Ciobotaru, and F. Blaabjerg, "Power electronics control of wind energy in distributed power systems," in 2008 11th International Conference on Optimization of Electrical and Electronic Equipment, 2008, pp. XXIX-XLIV.

[9] M. Beaudin, H. Zareipour, A. Schellenberglabe, and W. Rosehart, "Energy storage for mitigating the variability of renewable electricity sources: An updated review," Energy for sustainable development, vol. 14, pp. 302314, 2010.

[10]H. Holttinen, L. Söder, and E. Ela, Design and operation of power systems with large amounts of wind power: Final report, IEA WIND Task 25, Phase one 2006-2008: VTT Technical Research Centre of Finland, 2009.

[11]A. S. Brouwer, M. Van Den Broek, A. Seebregts, and A. Faaij, "Impacts of large-scale Intermittent Renewable Energy Sources on electricity systems, and how these can be modeled," Renewable and sustainable energy reviews, vol. 33, pp. 443-466, 2014.

[12]C. H. Lo and M. D. Anderson, "Economic dispatch and optimal sizing of battery energy storage systems in utility load-leveling operations," IEEE Transactions on Energy Conversion, vol. 14, pp. 824-829, 1999.
[13]S. Bae, S. U. Jeon, and J.-W. Park, "A study on optimal sizing and control for hybrid energy storage system with SMES and battery," IFAC-Papers OnLine, vol. 48, pp. 507-511, 2015.

[14]T. Borsche, A. Ulbig, M. Koller, and G. Andersson, "Power and energy capacity requirements of storages providing frequency control reserves," in 2013 IEEE Power \& Energy Society General Meeting, 2013, pp. 15.

[15]H. Nazaripouya, Y. Wang, P. Chu, H. R. Pota, and R. Gadh, "Optimal sizing and placement of battery energy storage in distribution system based on solar size for voltage regulation," in 2015 IEEE Power \& Energy Society General Meeting, 2015, pp. 1-5.

[16]G. J. May, A. Davidson, and B. Monahov, "Lead batteries for utility energy storage: A review," Journal of Energy Storage, vol. 15, pp. 145-157, 2018.

[17]S. Wang, Y. Tang, J. Shi, K. Gong, Y. Liu, L. Ren, and J. Li, "Design and advanced control strategies of a hybrid energy storage system for the grid integration of wind power generations," IET Renewable Power Generation, vol. 9, pp. 89-98, 2014.

[18]J. P. Fossati, A. Galarza, A. Martín-Villate, and L. Fontan, "A method for optimal sizing energy storage systems for microgrids," Renewable Energy, vol. 77, pp. 539-549, 2015.

[19] A. A. Sallam and O. P. Malik, Power system stability: modelling, analysis and control: The Institution of Engineering and Technology, 2015.

[20]B. Zhao, X. Zhang, J. Chen, C. Wang, and L. Guo, "Operation optimization of standalone microgrids considering lifetime characteristics of battery energy storage system," IEEE Transactions on Sustainable Energy, vol. 4, pp. 934-943, 2013.

[21] S. Kumar, A. Kumar, and N. Sharma, "Analysis of power flow, continuous power flow and transient stability of IEEE-14 bus integrated wind farm using PSAT," in 2015 International Conference on Energy Economics and Environment (ICEEE), 2015, pp. 1-6.

[22] J. G. Slootweg, "Wind power: Modelling and impact on power system dynamics," 2003.

[23] B. Tamimi, C. Cañizares, and K. Bhattacharya, "System stability impact of large-scale and distributed solar photovoltaic generation: The case of Ontario, Canada," IEEE Transactions on Sustainable Energy, vol. 4, pp. 680-688, 2013.

[24] F. Milano, "An open source power system analysis toolbox," IEEE Transactions on Power Systems, vol. 20, pp. 1199-1206, 2005. 